\title{
Pemberdayaan Potensi Sosial Masyarakat Muslim Melalui Yayasan Aksi Cepat Tanggap (ACT) Bandung
}

\author{
Irma Nuraeni* \\ Fakultas Dakwah dan Komunikasi UIN Sunan Gunung Djati, Bandung \\ *Email:rmnuraeni@gmail.com
}

\begin{abstract}
Humanitarian issues are the main thing that needs to be developed for the development of community welfare both in the social, educational, economic and religious fields. This writing aims to find out the existence of the Aksi Cepat Tanggap Foundation (ACT) in the midst of the Bandung community in developing strong potential and civil society development that has the potential to empower and develop the community. The research method used is a field study method by conducting surveys, interviews and documentation directly to the Foundation branch office. Processing and analysis of data includes the process of collecting data, classifying data, connecting data with one another, analyzing data, and drawing conclusions. The results of the study show that the community has understood the vision and mission of the foundation, growing a high level of trust given by the community to Aksi Cepat Tanggap (ACT), the growth and development institutions become large from the massive donations of the community. Aksi-Aksi Cepat Tanggap (ACT) has been able to create community trust that is characterized by the large mandate and contribution of the community. The excitement of Aksi Cepat Tanggap (ACT) accepts the mandate and distributes it quickly, reaping appreciation from the community. Even the government entrusts its community donations to be channeled by Aksi Cepat Tanggap (ACT) in bumanitarian missions
\end{abstract}

Keywords: Development; Volunteer;Philanthropy;Humanity

\begin{abstract}
ABSTRAK
Persoalan kemanusiaan menjadi hal utama yang perlu dikembangkan untuk pembangunan kesejahteraan masyarakat baik dalam bidang sosial, pendidikan, ekonomi maupun keagamaan. Penulisan ini bertujuan untuk mengetahui eksistensi Yayasan Aksi Cepat Tanggap (ACT) ditengah masyarakat Bandung dalam pengembangan potensi dan pembangunan masyarakat sipil yang kuat yang sangat berpotensi dalam pemberdayaan dan pengembangan masyarakat. Metode penelitian yang digunakan yaitu metode studi lapangan dengan cara melakukan survei, wawancara dan dokumentasi langsung ke kantor cabang Yayasan. Pengolahan dan analisis data meliputi proses pengumpulkan data, klasifikasi data, menghubungkan data satu dengan yang lain, analisis data, dan penarikan kesimpulan. Hasil penelitian menunjukkan bahwa masyarakat telah mengerti bagaimana visi dan misi yayasan, tumbuh kepercayaan tinggi yang diberikan masyarakat kepada Aksi Cepat Tanggap (ACT), lembaga-lembaga tumbuh kembang menjadi besar dari donasi masyarakat yang begitu masif. Aksi-Aksi Cepat Tanggap (ACT) telah mampu menciptakan kepercayaan masyarakat yang ditandai dengan besarnya amanat dan kontribusi masyarakat. Kegesitan Aksi Cepat Tanggap (ACT) menerima amanat dan menyalurkan secara cepat, menuai apresiasi dari lapisan masyarakat. Bahkan pemerintah mempercayakan donasi masyarakatnya untuk disalurkan oleh Aksi Cepat Tanggap (ACT) dalam misi kemanusiaan
\end{abstract}

Kata Kunci : Pemberdayaan;Relawan;Filantropi;Kemanusiaan 


\section{Nuraeni}

\section{PENDAHULUAN}

Sejak awal dalam sejarah Bandung tumbuh di tengah arus keadaan sistem sosial politik dan kebudayaan yang berbeda-beda di suatu masyarakat secara terusmenerus menimbulkan perubahan di tata hidup masyarakatnya. Perbedaan ini mengarah kepada pembangunan yang sesungguhnya belakangan ini sering dikaji dalam kerangka yang sering disebut dengan masyarakat madani. Secara sederhana ia dipandang sebagai tatanan masyarakat yang berperadaban (civilized society), yaitu masyarakat yang dibangun di atas nilai-nilai yang berlaku untuk semua orang atau seluruh dunia.

Dengan melihat pembangunan sosial kemasyarakatan yang terus-menerus menimbulkan perubahan kehidupan masyarakat dalam arah kemajuan maupun perkembangan penduduk, Bandung kini dan dalam masa yang akan datang berada dalam pelbagai tarikan yang seringkali sukar dipecahkan. Pendekatanagama menjadi alternatif dari pelbagai pendekatan yang dapat ditawarkan. Persoalan kemanusiaan pun menjadi hal utama yang perlu dikembangkan ditengah globalisasi dan masyarakat modern yang cenderung bersifat apatis terhadap masyarakat lainnya, seperti yang terjadi pada saat ini adalah ketidakpedulian masyarakat satu dengan lainnya yang berhubungan dengan pembangunan kesejahteraan masyarakat baik dalam bidang sosial, pendidikan, ekonomi maupun keagamaan.

Manusia sejatinya adalah yang menjunjung tinggi kebaikan dan berupaya melakukan perbaikan di muka bumi, maka seharusnya akan menjadi lebih mudah untuk saat ini juga, untuk ikut serta dalam barisan "pembawa solusi". Sendiri-sendiri pastilah berpeluang besar mengalami kesulitan, namun disamping itu keyakinan bahwa ketika menyatukan kekuatan yang dimiliki, dan bersama-sama menyebarkan kepada siapapun yang ditemui untuk meningkatkan kesadaran bergerak demi kemanusiaan, maka yang sedikit-sedikit itu akan menjadi gelombang gerakan kemanusiaan yang tak terbendung.

Persoalan kemanusiaan pun menjadi hal utama yang perlu dikembangkan ditengah globalisasi dan masyarakat modern yang cenderung bersifat apatis terhadap masyarakat lainnya, seperti yang terjadi pada saat ini adalah ketidakpedulian masyarakat satu dengan lainnya yang berhubungan dengan pembangunan kesejahteraan masyarakat baik dalam bidang sosial, pendidikan, ekonomi maupun keagamaan. Kehadiran Aksi Cepat Tanggap (ACT) ditengah masyarakat Bandung yang bergerak dibidang sosial keagamaan untuk membela kepentingan dan hak-hak masyarakat dengan berorientasi pada pembangunan masyarakat sipil yang kuat sangat berpotensi dalam pengembangan masyarakat, untuk memperluas karyanya melalui pengembangan aktivitasnya, mulai dari kegiatan tanggap darurat, kemudian mengembangkan kegiatannya ke program pemulihan pascabencana, pemberdayaan dan pengembangan masyarakat, serta program berbasis spiritual seperti Qurban, Zakat dan Wakaf. Dalam prosesnya 
yaitu pemberdayaan berbasis kedermawanan dan kerelawanan.Yayasan Aksi Cepat Tanggap (ACT) Bandung yang bergerak di bidang sosial dan kemanusiaan.beralamat di Jl Gitar No. 21 RT 02/10, Kelurahan Turangga Kecamatan Lengkong, Bandung 40264, Jawa Barat. Aksi Cepat Tanggap (ACT) didukung oleh donatur publik dari masyarakat yang memiliki kepedulian tinggi terhadap permasalahan kemanusiaan dan juga partisipasi perusahaan melalui program kemitraan dan Corporate Social Responsibility (CSR). Sebagai bagian dari akuntabilitas keuangannya secara rutin memberikan laporan keuangan tahunan yang telah diaudit oleh Kantor Akuntan Publik kepada donatur dan pemangku kepentingan lainnya, serta mempublikasikannya melalui media massa.

Oleh karenanya sungguh sesuatu yang logis bahwakepedulianadalah jawabansejati danpermanen darisegala apa permasalahandi duniaini saatini, yangbanyak bersumberdari semakintidakpedulinya manusia, satudenganyang lain.Sebuahstrategi pencapaianmenuju kemandirianmasyarakat dan kesuksesan dari fungsimasyarakat. Namunpada saatyang sama, menjaditujuan daristrategi itusendiri, yaituberupa terbentuknyalingkaran hidupkepedulian - kemandirian masyarakat. Kiranyabila ituterjadi, ketika manusia telah mampu melakukan segalayangperludilakukan untukperbaikan di muka bumi, atas dasar kemanusiaan dankebaikan belaka, tanpa tersekat-sekat dalam batas-batas apapun, maka kita pun menjadi human at its best. Manusia dalam sifat "terbaik"-nya, duniadanakhirat. Potensi modal sosial merupakan jawaban dari persoalan yang terjadi pada masyarakat. Darilatar belakangmasalahdiatas,dapat disimpulkan beberaparumusan masalahyaitu bagaimanatrust (kepercayaan) masyarakat, akuntabilitas dan transparansi terhadap yayasan Aksi Cepat Tanggap (ACT) dalam mengelola dan memberdayakan potensi sumber daya masyarakat.

Penelitian sebelumnya yang berkaitan dengan penelitian yang sudah dilakukan salah satunya yaitu penelitian Mustangin dkk. (2017) tentang pemberdayaan masyarakat berbasis potensi lokal melalui program desa wisata di Desa Bumiaji. Dalam penelitiannya enyebutkan, pemberdayaan masyarakat dilakukan dengan mengoptimalkan program desa wisata untuk dijadikan komoditi pariwisata berbasis potensi lokal masyarakat. Desa wisata di Bumiaji telah memberikan perubahan bagi masyarakat terlebih pada peningkatan pengetahuan dan perekonomian masyarakat.

Kemudian Sukmana (2010), yang berjudul "Konsep Pemberdayaan Masyarakat melalui Pengembangan Komunitas Berbasis Potensi Lokal (Studi Di Desa Wisata Bunga Sidomulyo, Kota batu Jawa Timur)'. Menurutnya, pengembangan kawasan binaan desa wisata bunga di daerah wisata kota Batu, Malang, adalah model konsep yang baik dalam program pemberdayaan masyarakat (komunitas) berbasis potensi dan kearifan nilai lokal. program ini mampu meningkatkan daya tarik Daerah Tujuan Wisata (DTW) dalam 


\section{Nuraeni}

mendukung program pengembangan Kota Batu sebagai kota Pariwisata. Pengelolaan lingkungan hidup sebagai upaya terpadu untuk melestarikan fungsi lingkungan hidup yang meliputi kebijaksanaan penataan, pemanfaatan, pengembangan, pemeliharaan, pemulihan, pengawasan, dan pengendalian lingkungan hidup.

Penelitian keduanya memiliki kesamaan dengan penelitian ini yaitu megembangkan potensi daerah setempat yang digunakan untuk mendukung tercapainya tujuan. Sedangkan perbedaannya adalah dari segi pengembangan potensi, skripsi ini mengembangkan potensi modal sosial sedangkan kedua skripsi terdahulu melakukan pengembangan di bidang ekonomi.

Penelitian ini dilakukan melalui pendekatan kualitatif, sebagai penelitian lapangan yang bermaksud untuk memahami fenomena yang dialami oleh subjek penelitian, seperti halnya perilaku, motivasi, persepsi dan tindakan lainnya sebagai cara mendeskripsikan dalam bentuk kata-kata dan bahasa pada suatu konteks khusus yang alamiah dengan memanfaatkan berbagai metode ilmiah (Surakhmad, 1982).

Penelitian ini bersifat deskriptif kualitatif yang bertujuan untuk mengetahui latar belakang dari yayasan Aksi Cepat Tanggap (ACT) sebagai gerakan peduli sosial (Muhaimin, 2013) dalam pemberdayaan masyarakat dan proses pemberdayaan (community empowerment) serta pendekatan yang dilakukan terhadap potensi sosial masyarakat dan dampak atau hasil dari proses pengembangan potensi sosial di Kota Bandung.Dalampenelitian inipenulis menggunakandatakualitatif,yaitu datayang diperolehdidapatkan langsungdari yayasan Aksi Cepat Tanggap (ACT) sebagai sumber informasimengenai rumusanmasalah yang dikajidalampenelitianini mencangkup seputarprogramdari yayasan Aksi Cepat Tanggap (ACT) dalam melakukan pemberdayaan potensi sosial masyarakat di Kota Bandung

Sumber Data Penelitianyaitu data primer yaitu sumber data yang bersumber langsung melalui wawancara dengan founder atau presidendari ACT dan data sekunder yaitu bersumber dari kajian pustaka yang berkaitan dengan penelitian ini.

Teknik Pengumpulan datanya yaitu observasi, interview atau wawancara dan Dokumentasi. Adapun proses analisis data yang digunakan pada tiga sub proses berkaitan yaitu: Pertama, reduksi data yaitu meliputi seleksi data dan pemadatan data, catatan dan rekaman dari lapangan diringkas dan disederhanakan, diberi tanda dan dikelompokan. Kedua, penyajian data yaitu hasil dari pengumpulan data dan pengelompokan data yang diperoleh kemudian ditampilkan dalam bentuk gabungan informasi dan ringkasan yang disajikan dalam bentuk teks naratif, tabel, diagram, dan bagan. Ketiga, penarikan kesimpulan yaitu merupakan proses akhir dari analisis data yang dilakukan peneliti dengan mengambil kesimpulan atau memverifikasi data yang 
telah terkumpul sebelumnya.

\section{HASIL DAN PEMBAHASAN}

Secara konseptual, pemberdayaan atau pemberkuasaan yang akar katanya dari berdaya. Karenanya, ide pemberdayaan sangat lekat kaitannya dengan konsep mengenai kekuasaan. Kekuasaan seringkali dikaitkan dengan kemampuan untuk membuat orang lain melakukan apa yang diinginkan, terlepas dari keinginan dan minat mereka. Karena itu, dapat dihubungkan kemungkinan terjadinya proses pemberdayaan sangat tergantung pada dua hal:Pertama, bahwa kekuasaan dapat berubah. Jika kekuasaan tidak dapat berubah, pemberdayaan tidak mungkin terjadi dengan cara apapun. Kedua, bahwa kekuasaan dapat diperluas. Konsep ini menekankan pada pengertian kekuasaan yang tidak statis, melainkan dinamis.

Dengan demikian, pemberdayaan ialah sebuah proses dan tujuan. Sebagai proses, pemberdayaan adalah serangkaian kegiatan untuk memperkuat kekuasaan atau keberdayaan kelompok lemah dalam masyarakat, termasuk individu-individu yang mengalami masalah kemiskinan. Sebagai tujuan, maka pemberdayaan menunjuk pada keadaan atau hasil yang ingin dicapai oleh sebuah perubahan sosial; yaitu masyarakat yang berdaya, memiliki kekuasaan atau mempunyai pengetahuan dan kemampuan dalam memenuhi kebutuhan hidupnya baik yang bersifat fisik, ekonomi, maupun sosial, dan mandiri dalam melaksanakan tugastugas kehidupannya. Pengertian pemberdayaan sebagai tujuan seringkali digunakan sebagai indikator keberhasilan pemberdayaan sebagai suatu proses. (Suharto, 2005: 57-60)

Masyarakat merupakan suatu kesatuan yang utuh, yang terdapat beberapa individu didalam suatu wilayah atau daerah. Karenanya, masyarakat disebut pula dengan sekumpulan manusia yang cenderung memiliki daerah yang ditetapi. Dalam prosesnya, satu manusia dan manusia saling berkomunikasi bertukar informasi yang kemudian terbentuklah kelompok formal. Interaksi atau pertukaran informasi antar sesama manusia inilah yang menjadi poin penting untuk keberlangsungan hidup mereka. Beberapa ciri keberlanjutan dalam suatu masyarakat ialah adanya saling tukar informasi terjalin dengan intensitas yang sering, kebiasaan dan kedekatan antar sesama warga yang kuat. (Koentjaraningrat, 2009: 115-118).

Dari beberapa penjelasan diatas maka dapat ditarik kesimpulan bahwa masyarakat mempunyai andil dalam mengemukakan pendapatnya. Dalam arti lain, kumpulan individu yang bertukar informasi dan adanya komunikasi antar sesama manusia disebut pula sebagai suatu masyarakat. Mereka memiliki kesamaan kebiasaan, teritorial, identitas, norma, pengambilan keputusan, dan perasaan persatuan yang diikat oleh kesamaan.

Tujuan yang ingin dicapai dari pemberdayaan yaitu mejadikan individu dan 


\section{Nuraeni}

rakyat yang mandiri, baik dalam pandangan, sikap, dan mampu mempertanggung jawabkan pilihannya tersebut. Sikap tidak ketergantungan terhadap orang lain ialah suatu keadaan yang terjadi ketika masyarakat berpikir, memutuskan serta menyikapi suatu masalah dengan mempertimbangkan segala aspek terkait. Dengan demikian untuk bisa hidup tidak bergantung pada orang lain dibutuhkan motivasi menggunakan sumber daya kognitif, konatif, psikomotorik dan afektif, dan sumber daya lainnya yang bersifat fisik- material.

Melalui proses belajar maka masyarakat secara bertahap akan memperoleh kemampuan atau daya dari waktu ke waktu, dengan demikian akan terakumulasi kemampuan yang memadai untuk mengantarkan kemandirian mereka, apa yang diharapkan dari pember dayaan yang merupakan visualisasi dari pembangunan sosial ini diharapkan dapat mewujudkan komunitas yang baik dan masyarakatyang ideal (Teguh, 2004: 80-81).

Tahap Pemberdayaan Menurut Sumodiningrat pemberdayaan hanya sementara, yaitu sampai tujuan yang diinginkan bisa dikerjakan oleh masyarakat itu sendiri, akan tetapi tetap dalam pengawasan. (Sumodiningrat, 2000 dalam Teguh, 2004: 82). Jika dilihat dari pendapat tersebut, artinya bahwa pemberdayaan mengalami tahapan sampai pada Dari penjelasan diatas maka dapat diambil pengertian bahwa pemberdayaan didapat secara bertahap dari awal sampai pada titik akhir yang dimana masyarakat mampu memberdayakan potensi yang ada, namun dengan begitu akan tetap dilakukan pengawasan terhadap proses yang sedang diupayakan seperti pemberian motivasi, agar penurunan diminimalisir dengan baik.

Proses atau tahapan yang dilalui adalah pertama, tahap berpikir dan membentuk kebiasaan yang kemudian berbuah pada sikap sehingga merasa membutuhkan kapasitas diri. Kedua, tahap perubahan potensi diri berbentuk ilmu pengetahuan, kecakapan keterampilan agar terbuka wawasan dan memberikan keterampilan dasar sehingga dapat mengambil peran di dalam pembangunan. Ketiga, tahap peningkatan kemampuan intelektual, kecakapan keterampilan sehingga terbentuklah inisiatif dan kemampuan inovatif untuk mengantarkan pada kemandirian (Teguh, 2004: 83).

Potensi adalah kemampuan dasar dari sesuatu yang masih terpendam yang menunggu untuk diwujudkan menjadi suatu kekuatan nyata (Wiyono, 2006: 37). Dalam upaya untuk memelihara dan meningkatkan kesejahteraan, baik melalui dinamika internal maupun melalui interaksi dan interkoneksitas dengan lingkungan eksternalnya dilakukan dengan memanfaatkan modal sosial yang ada.

Dengan memanfaatkan modal sosial, secara internal dapat dibangun dan diperkuat kohesi sosial dan solidaritas sosial, secara eksternal dapat dibangun jaringan sosial yang lebih luas. Kohesi sosial dan solidaritas sosial akan terbangun 
manakala ada trust. Demikian juga dalam membangun jaringan dengan pihak eksternal, karena pada dasarnya membangun jaringan berarti memperluas ruang lingkup trust itu sendiri. Trust merupakan bentuk modal sosial yang paling penting sebagai landasan dalam membina kemitraan baik dengan masyarakat lain, dengan pemerintah maupun dunia usaha. Yang perlu diperhatikan terutama dalam menyesuaikan dengan perkembangan terkini adalah, agar trust terutama dalam hubungannya dengan berbagai pihak eksternal dapat dipelihara bahkan ditingkatkan, perlu diimbangi dengan akuntabilitas dan transparansi, yang memberikan peluang bagi stakeholder untuk mengawasi atau memverifikasi apa yang sudah dilakukan masyarakat dalam rangka kerja sama dan kemitraan. Trust bersifat dinamis karena ia dapat tumbuh dan sebaliknya dapat hilang manakala mereka yang mendapat mandat kepercayaan ternyata tidak dapat bertanggungjawab (tidak akuntabel) terhadap mandat yang telah diberikan. Dengan demikian yang dibutuhkan bukan hanya memanfaatkan trust sebagai salah satu modal, potensi dan sumber daya sosial, melainkan juga memelihara dan memupuknya.

Lembaga merupakan wadah atau tempat orang-orang berkumpul, bekerja sama secara berencana terorganisasi, terkendali, terpimpin dengan memanfaatkan sumber daya untuk satu tujuan yang sudahditetapkan. Lembaga kemasyarakatan pada intinya adalah suatu tatanan sosial yang mempunyai fungsi sebagai: Pertama, pedoman kepada para anggotanya tentang bagaimana harus bersikap dan bertingkahlaku dalam mengurus dan menyelesaikan kebutuhannya. Kedua, menjaga dan mempertahankan keutuhan masyarakat.

Ketiga,memberipegangan kepada masyarakat untuk dapat mengadakansistem pengendalian sosial (social control) ialah suatu sistempengawasan terhadap tingkah laku anggota masyarakatnya.

Ciri-ciri umum lembaga kemasyarakatan itu antara lain: (Sumardjan, 1964: 70): Merupakan unit yang fungsional, merupakan organisasi pola pemikiran dan pola perilaku yang terwujud melalui aktivitas kemasyarakatan dan hasil-hasilnya, mempunyai tingkat kekekalan tertentu, yaitu telah teruji dan berupa himpunan norma-norma pencapaian kebutuhan, mempunyai tujuan atau beberapa tujuan tertentu.Tipe-tipe lembaga kemasyarakatan yaitu berdasarkan perkembangannya, berdasarkan sudut nilainilai yang diterima oleh masyarakat, dari sudut penerimaan masyarakat, dari sudut fungsinya.

Safei berpendapat yang artinya bahwa konsepnya, rumus bisnis (bisnis dengan Tuhan) selestial relevan untuk pengembangan aspek ekonomi masyarakat Islam. Formula ini menawarkan keseimbangan antara kepuasan material dan kebutuhan spiritual, atau kebutuhan fisik dan spiritual. Pada tingkat yang lebih 


\section{Nuraeni}

tinggi, ini bisa menjadi formula alternatif untuk mengembangkan aspek ekonomi masyarakat Islam (Safei, 2016:13)

Yayasan Aksi Cepat Tanggap (ACT) Bandung beralamat di Jl Gitar No. 21 RT 02/10, Kelurahan Turangga Kecamatan Lengkong, Bandung 40264, Jawa Barat.Aksi Cepat Tanggap (ACT) secara resmi diluncurkan secara hukum sebagai yayasan pada tanggal 21 April 2005, bergerak di bidang sosial dan kemanusiaan.Untuk memperluas karya, Aksi Cepat Tanggap (ACT) mengembangkan aktivitasnya mulai dari kegiatan tanggap darurat, kemudian mengembangkan kegiatannya ke program pemulihan pasca bencana, pemberdayaan dan pengembanganmasyarakat, serta program berbasis spiritual seperti Qurban, Zakat dan Wakaf.

Aksi Cepat Tanggap (ACT) didukung oleh donatur publik dari masyarakat yang memiliki kepedulian tinggi terhadap permasalahan kemanusiaan dan juga partisipasi perusahaan melalui program kemitraan dan Corporate Social Responsibility (CSR). Sebagai bagian dari akuntabilitas keuangannya secara rutin memberikan laporan keuangan tahunan yang telah diaudit oleh Kantor Akuntan Publik kepada donatur dan pemangku kepentingan lainnya, serta mempublikasikannya melalui media massa. Sejak tahun 2012 Aksi Cepat Tanggap (ACT) mentransformasi dirinya menjadi sebuah lembaga kemanusiaan global, dengan jangkauan aktivitas yang lebih luas. Pada skala lokal, Aksi Cepat Tanggap (ACT) mengembangkan jejaring ke semua provinsi baik dalam bentuk jaringan relawan dalam wadah MRI (Masyarakat Relawan Indonesia) maupun dalam bentuk jaringan kantor cabang Aksi Cepat Tanggap (ACT). Jangkauan aktivitas program sekarang sudah sampai ke 30 provinsi dan 100 kabupaten atau kota di seluruh Indonesia.

Pada skala global, Aksi Cepat Tanggap (ACT) mengembangkan jejaring dalam bentuk representative person sampai menyiapkan kantor di luar negeri. Jangkauan aktivitas program global sudah sampai ke 22 Negara di kawasan Asia Tenggara, Asia Selatan, Indocina, Timur Tengah, Afrika, Indocina dan Eropa Timur. Wilayah kerja di skala global diawali dengan kiprah dalam setiap tragedi kemanusiaan di berbagai belahan dunia seperti bencana alam, kelaparan dan kekeringan, konflik dan peperangan, termasuk penindasan terhadap kelompok minoritas berbagai negara.

Dengan spirit kolaborasi kemanusiaan, Aksi Cepat Tanggap (ACT) mengajak semua elemen masyarakat dan lembaga kemanusiaan untuk terlibat bersama. Berbekal pengalaman selama puluhan tahun di dunia kemanusiaan, kami melakukan edukasi bersama, membuka jaringan kemitraan global yang menjadi sarana kebersamaan. Semua program global menjadi sarana merajut kemitraan berbagai lembaga amil zakat, komunitas peduli, artis dan publik figur yang memiliki visi yang sama untuk kemanusiaan.Tahun 2014 menjadi awal bagi Aksi Cepat Tanggap (ACT) untuk menjalin kolaborasi kemanusiaan dunia, 
bersamaan dengan visi baru:menjadi lembaga kemanusiaan global profesional, berbasis kedermawanan dan kerelawanan masyarakat global, kami ingin mewujudkan peradaban dunia yang lebih baik. Menghadirkan sebuah dunia yang nyaman bagi umat manusia, dunia beradab dan memiliki peradaban mulia di bawah naungan cahaya ilahi. Cita-cita ini akan menjadi nyata dengan keterlibatan semua pihak. Kami memiliki keyakinan penuh, bantu kami untuk bersama mewujudkannya.

Aksi Cepat Tanggap (ACT) percaya akan hadir peradaban dunia yang lebih baik. Semua permasalahan kemanusiaan dapat diselesaikan dengan membangun kedermawanan dan kerelawanan global. "Let's ACT Indonesia" adalah sebuah ajakan bagi masyarakat di mana pun berada, untuk membuktikan kepedulian sebagai manusia. Bersama untuk berkolaborasi dalam berbagai bentuk kepedulian sebagai solusi isu-isu kemanusiaan baik di Indonesia dan penjuru dunia.

Legal Hukum Yayasan Aksi Cepat Tanggap (ACT) Bandung a) Akta pendirian yayasan Aksi Cepat Tanggap (ACT) No. 2 tanggal 21 April 2005 pejabat notarisnya Mina Ng. AH.,Mkn. b) Akta pernyataan keputusan rapat yayasan Aksi Cepat Tanggap (ACT) No. 1 tanggal 8 April 2009 dengan notaris Ny. Trie Sulistiowati, SH. c) Pengesahan dengan keputusan Menteri Hukum dan Hak Asasi Manusia Republik Indonesia No. C-1714.RT.01.02 Tahun 2005. d) Surat keterangan Departemen Sosial Direktorat Jenderal Bantuan dan Jaminan Sosial No. 33/BSKBA/I/2006 yang menyatakan bahwa Yayasan Aksi Cepat Tanggap adalah mitra Departemen Sosial sebagai Satuan Penanggulangan Bencana Bidang Bantuan Sosial di seluruh Indonesia. e) Surat tanda daftar yayasan atau organisasi sosial No 460/167-36 BANJAMSOSO/VI/2017 yang dikeluarkan di Tangerang Selatan pada tanggal 10 Juni 2017 oleh Kepala Dinas Ketenagakerjaan dan Transmigrasi

Visi dan Misi Yayasan Aksi Cepat Tanggap (ACT) Bandung, Visinya yaitu menjadi organisasi kemanusiaan global profesional berbasis kedermawanan dan kerelawanan masyarakat global untuk mewujudkan peradaban dunia yang lebih baik. Sedangkan misi nya yaitu pertama, mengorganisir dan mengelola berbagai persoalan kemanusiaan secara terencana, terkonsep, terintegrasi, dan berkesinambungan sehingga menjadi formula ideal dalam mengatasi berbagai problem kemanusiaan baik dalam skala lokal, nasional, regional, maupun global. Kedua, mengorganisir dan mengelola segala potensi kedermawanan masyarakat global sebagai modal sosial untuk mengatasi berbagai problem kemanusiaan baik dalam skala lokal, nasional, regional, maupun global. Ketiga, mengorganisir dan mengelola segala potensi kerelawanan global sebagai modal sosial untuk mengatasi berbagai problem kemanusiaan baik dalam skala lokal, nasional, regional, maupun global. 


\section{Nuraeni}

\section{Kepercayaan (Trust) Masyarakat Terhadap Yayasan Aksi Cepat Tanggap (ACT)}

Aksi Cepat Tanggap (ACT) ialah organisasi non profit, hal tersebut dapat diketahui dari visi dan misi organisasi. Selain itu program-program di lapangan juga merupakan program sosial dan kemanusiaan yang tidak mengandung unsur pencarian laba. Aksi Cepat Tanggap (ACT) menunjukkan eksistensi dan kegesitannya pada fase darurat (emergency), pemulihan (recovery) dengan menggulirkan berbagai program. Aksi kemanusiaan yang dilakukan berorientasi amal (charity) dengan memberdayakan sumber daya lokal (local sources).

Perkembangan Aksi Cepat Tanggap (ACT) sebagai sebuah lembaga berbasis kemanusiaan hingga sebesar sekarang meniscayakan bahwa masyarakat telah mengerti bagaimana visi dan misi lembaga dirumuskan, serta mengikuti dari waktu ke waktu hingga bagaimana kepercayaan tinggi diberikan masyarakat kepada Aksi Cepat Tanggap (ACT). Banyak sekali lembaga-lembaga tumbuh kembang menjadi besar dari donasi masyarakatyang begitu masif.Adapun kegiatan yang dilakukan oleh Aksi Cepat Tanggap (ACT) adalah melalui kegiatan internal dan eksternal. Kegiatan internal mencangkup loyalitas pegawai atau relawan terhadap Yayasan Aksi Cepat Tanggap (ACT) yang memberikan pengaruh kepada kepercayaan masyarakat dalam menitipkan donasi yang akan disalurkan. Sedangkan kegiatan eksternal yang dilakukan guna membuktikan kepercayaan masyarakat dalam menitipkan donasi untuk disalurkan dalam misi kemanusiaan yang dilakukan Aksi Cepat Tanggap (ACT). Kegiatan tersebut dibagi menjadi dua yaitu kegiatan internal dan eksternal.

Kegiatan InternalKinerja dan loyalitas pegawai atau relawan Aksi Cepat Tanggap (ACT) menjadi komponen yang sangat penting dan berpengaruh kepada kepercayaan masyarakat dalam menitipkan amanah atau donasi yang akan disalurkan. Keberadaan relawan hampir tidak dapat dipisahkan dengan keberadaan lembaga kemanusiaan. Relawan sebagai salah satu sumber daya manusia yang sangat potensial dalam suksesnya pelaksanaan kegiatan misi kemanusiaan atau pelayanan sosial Yayasan Aksi Cepat Tanggap (ACT). Potensi sosial relawan itu dapat dilihat dari motivasi, kiprah di bidang pelayanan sosial, dan keselarasan visi dan misi relawan dengan lembaga kemanusiaan tersebut. Besarnya potensi yang dimiliki pegawai atau relawan ini membuat posisi dan peran mereka dalam kegiatan kemanusiaan menjadi sangat penting.

Di dalam pengembangan sumber daya potensi sosial relawan mencangkup pengakuan dan penghargaan, pendidikan dan pelatihan, serta bentuk lainnya yang ditujukan untuk pengembangan.

Pelatihan dan pembekalan skill saja tidak cukup untuk mengasah kepekaaan relawan terhadap lingkungan sosialnya. Maka tahap lanjutan paska pelatihan adalah pelibatan relawan dalam aksi-aksi kemanusiaan. Relawan diberikan kesempatan untuk terlibat aktif dan terjun langsung dalam Respons atas 
Bencana Alam dan Bencana Kemanusiaan di dalam negeri maupun Dunia Internasional.

Dalam pengembangan tentunya diperlukan metode untuk memudahkan tercapainya tujuan, metode dakwah merupakan salah satu unsur dakwah yang memiliki peran penting dan strategis untuk keberhasilan dakwah. Metode dakwah senantiasa mengalami perkembangan sesuai dengan perkembangan situasi dan kondisi jamannya. Namun demikian secara esensial al-Quran telah memberikan landasan yang baku berkenaan dengan prinsip-prinsip yang harus dibangun dalam berbagai ragam metode dakwah. Prinsip ini diantaranya termuat dalam surat al-Nahl ayat 125yaitu: al-Hikmah, al-mauidzah al-hasanah, dan al-mujadalah al-ahsan, kemudian teraktualkan dan diperkuat dengan prinsipprinsip dakwah yang dilakukan oleh Rasulullah Muhammad saw. (Aliyudin, 2009)

Selain terlibat dalam aksi-aksi bersama Aksi Cepat Tanggap (ACT), relawan juga diberikan kesempatan untuk terlibat total dalam program-program pendampingan maupun pemberdayaan masyarakat, dengan model kegiatan: 1) Kuliah Kerja Relawan atau Bakti Kerja Relawan. Relawan mendedikasikan waktu dan segala potensinya dalam mendorong serta membersamai masyarakat di komunitas pilihannya untuk meningkatkan kualitas kehidupannya di berbagai bidang baik pendidikan, kesehatan, ekonomi, dan lain-lain. Relawan secara berkelompok mneyiapkan konsep program, merencanakan dan implementasi langsung bersama dengan masyarakat.

Jangka waktu kegiatan ini disepakati bersama antara relawan dan komunitas atau masyarakat. 2) Relawan Pendamping Masyarakat, Relawan berperan sebagai Pembina sekaligus fasilitator yang mendampingi masyarakat dalam menjalani program peningkatan kualitas hidup terutama di bidang ekonomi dan pembinaan mental spiritual. 3) Mobile Volunteer, Aksi regular yang dilaksanakan relawan untuk membantu masyarakat dari satu tempat ke tempat lainnya. Baik dalam bentuk layanan kesehatan, pemberian paket pangan, aksi bersama bersih lingkungan, dll. Semua kegiatan diinisiasi dan dilaksanakan relawan dalam bentuk tim yang solid dan beraksi dengan dikoridori konsep dan perencanaan yang matang sehingga program aksi yang dijalankan dapat dirasakan manfaatnya oleh masyarakat.

Kepercayaan (trust) dari pihak relawan atau pegawai terhadap lembaga kemanusiaan terlihat pada kiprahnya. Bentuk kepercayaan tersebut terlihat saat adanya koordinasi dan evaluasi antara relawan dan pihak masyarakat relawan Indonesia. Mereka melibatkan masyarakat setempat pula untuk menjadi relawan yang membantu dalam perbantuan dan penyaluran misi kemanusiaan. Hal mendasar yang diperlukan yang ada pada diri relawan atau pegawai yaitu integritas (kejujuran dan bersikap sebenarnya), kemampuan meliputi 


\section{Nuraeni}

pengetahuan dan keterampilan teknis, konsistensinya dalam mengemukakan gagasan dan informasi. Hal ini menjadi komponen penting dalam membangun kepercayaan yang membantu mengembangkan suatu lingkungan kerja yang kondusif pun membantu dalam proses pemecahan masalah.

Kegiatan Eksternal, Pada skala lokal, Aksi Cepat Tanggap (ACT) mengembangkan jejaring ke semua provinsi baik dalam bentuk jaringan relawan dalam wadah MRI (Masyarakat Relawan Indonesia) maupun dalam bentuk jaringan kantor cabang Aksi Cepat Tanggap (ACT). Jangkauan aktivitas program sekarang sudah sampai ke 30 provinsi dan 100 kabupaten atau kota di seluruh Indonesia. Salah satu program pemberdayaan yang berada di Bandung yaitu pemberdayaan santri, dengan pemberian bibit ikan di dua pondok Pesantren di Priangan Timur, Jawa Barat, yaitu: Pondok Pesantren Miftahul Huda 2 di Desa Bayasari Kecamatan Jatinagara-Kabupaten Ciamis dan di Pondok Pesantren AtTaslim di Kampung Citiis RT 02 RW 11, Desa Warnasari, Kecamatan Pangalengan, Kabupaten Bandung.

Program bantuan bibit ikan ini bertujuan sebagai upaya peningkatan pemberdayaan ekonomi serta membentuk karakter mandiri para santri, Program pemberian bibit ikan ini juga dilakukan untuk pemanfaatan lahan yang ada di pondok pesantren, sehingga terisi dan berdaya guna. Kemudian relawan dari Aksi Cepat Tanggap (ACT) membantu memasarkannya dan guru atau mentor di pesantren tersebut yang membimbing bagaimana cara memberi pakan, bagaimana cara mengembangbiakannya kepada santri di pesantren tersebut. Pemilihan bibit ikan pun disesuaikan dengan masing-masing lokasi. Di Ciamis misalnya, jenis ikan sesuai dengan arahan salahsatu pengurus Pesantren Mifhtahul Huda 2, yang menyarankan agar memlilih bibit ikan lele, maka sesuai dengan arahan Pengurus Pesantren Miftahul Huda 2, Tim Aksi Cepat Tanggap (ACT) pun membeli bibit ikan lele. Kurang lebih hampir 10 ribu bibit Ikan Lele Sangkuriang seukuran ibu jari. Sedangkan untuk Pesantren At- Taslim Tim Aksi Cepat Tanggap (ACT) memberikan ikan mas, ikan nila hitam, ikan nila merah serta ikan graskap.

Aksi Cepat Tanggap hadir sebagai solusi dalam pemberdayaan masyarakat agar meningkatnya derajat atau kondisi ekonomi pada rakyat yang kini dalam keadaan sulit untuk berlepas diri dari kemiskinan dan keterbelakangan. (Kartasasmita, 1997)

Pemberdayaan tersebut merupakan salah satu langkah untuk menanamkan jiwa wirausaha pada masyarakat yang kemudian akan menjadi potensi untuk meningkatkan kesejahteraanPada skala global, Aksi Cepat Tanggap (ACT) mengembangkan jejaring dalam bentuk representative person sampai menyiapkan kantor di luar negeri. Jangkauan aktivitas program global sudah sampai ke 22 Negara di kawasan Asia Tenggara, Asia Selatan, Timur Tengah, Afrika, Indocina dan Eropa Timur. Wilayah kerja di skala global diawali dengan 
kiprah dalam setiap tragedi kemanusiaan di berbagai belahan dunia seperti bencana alam, kelaparan dan kekeringan, konflik dan peperangan, termasuk penindasan terhadap kelompok minoritas berbagai negara. Sehingga, pemberdayaan pada intinya ialah suatu instrumen atau komponen yang diperlukan untuk mencapai fungsinya, Artinya, diharapkan dapat menguatkan daya tampung sekelompok anggota sosial atau komunitas yang bisa mengubah kondisi masyarakat, serta mempunyai daya dorong untuk perubahan kearah kemajuan yang dibutuhkan oleh masyarakat. (Risyanti, 2006)

Dengan menggulirkan aksi-aksi kemanusiaan, Aksi Cepat Tanggap (ACT) mampu menciptakan kepercayaan masyarakat yang ditandai dengan besarnya amanat dan kontribusi masyarakat. Kegesitan Aksi Cepat Tanggap (ACT) menerima amanat dan menyalurkan secara cepat, banyak menuai apresiasi dari lapisan masyarakat. Seperti contohnya adalah Walikota Bandung mempercayakan donasi masyarakatnya untuk disalurkan oleh Aksi Cepat Tanggap (ACT) dalam misi kemanusiaan.Lembaga kemanusiaan basisnya adalah trust. Semakin tinggi kepercayaan yang dimiliki sebuah lembaga sosial kemanusiaan, semakin besar donasi (dalam bentuk dana dan barang) mengalir kepadanya. Kepercayaan yang makin tinggi, melahirkan amanat besar. Amanat besar menuntut kapasitas besar (hebat). Kapasitas yang makin besar melahirkan kepercayaan yang makin besar.

\section{Akuntabilitas Yayasan Aksi Cepat Tanggap (ACT)}

Aksi Cepat Tanggap senantiasa memperbaharui laporan donasi dan di audit oleh Kantor Akuntan Publik Independen (Independent Auditor's Report), pada prinsipnya Aksi Cepat Tanggap (ACT) sangat menjunjung asas prudensialitas, sehingga publik dapat berdonasi dengan pertanggungjawaban yang baik. Adapun manajemen Aksi Cepat Tanggap (ACT) agar tetap prudensial dan terpercaya yaitu: komunikasi, sosial dan niat. Pertama, audit komunikasi yaitu parameter capaian komunikasi yang diukur tanpa campur tangan lembaga khusus, tidak lebih rendah derajat objektivitasnya. Misalnya, komunikasi ACT di media sosial bisa terpantau tanpa intervensi. Jika materi kampanye dipandang baik, kuat, dan menginspirasi, publik yang direpresentasikan netizen akan obyektif menilainya. Suka atau tidak, bisa disaksikan setiap saat.

Kerja media sosial terpantau publik dan hasilnya pun bisa segera diketahui. Pengalaman menunjukkan, materi kampanye live report aksi di lapangan hampir selalu memperoleh reaksi positif dan itu otomatis menjadi indikator besar kecilnya kepercayaan. Maka Aksi Cepat Tanggap (ACT) melekatkan keharusan live report untuk setiap implementasi program masterpiece-nya.Contoh terkini, live report yang dilakukan pada bulan Ramadan saat Aksi Cepat Tanggap (ACT) menyerahkan 1.000 ton beras amanah masyarakat Indonesia ke tangan pemerintah Somalia di pelabuhan Mogadishu. Publik meresponnya luar biasa 


\section{Nuraeni}

hanya dalam hitungan menit. Hal serupa terjadi saat Aksi Cepat Tanggap (ACT) menunaikan amanah berupa iftar bersama anak-anak pengungsi Suriah di Reyhanli, disusul aktivitas belanja pakaian anak-anak gratis di toko mitra

Aksi Cepat Taggap (ACT) di Mersin, keduanya di Turki. Penonton live report aktivitas ini mengundang keharuan publik Indonesia. Padahal untuk waktu Indonesia, laporan itu sudah lewat tengah malam. Kedua, audit sosial. Ini terkait kemanfaatan program Aksi Cepat Tanggap (ACT). Sebelum diaudit publik dalam arti publik memandang implementasinya baik, progresif atau tidak layak, dan mengada-ada bahwa Aksi Cepat Tanggap (ACT) sudah melakukan selfaudit.Ketiga, "audit niat". Ini disadari orang per orang. Setiap individu diajak berefleksi, seberapa hebat niat berkarya di Aksi Cepat Tanggap (ACT). Tanpa niat kuat dan pikiran luas berfilantropi, tanpa niat kuat untuk beribadah, bekerja di Aksi Cepat Tanggap (ACT) akan menjadi siksaan. Maka, "luruskan niat" menjadi saran pertama bagi individu baru Aksi Cepat Tanggap (ACT). Yang ini, tentu setiap orang tak bisa menakarnya, sudah kewenangan Allah.

Frasa "luruskan niat" sudah terngiang di setiap telinga individu di Aksi Cepat Tanggap (ACT). Di atas audit finansial, ada "segitiga audit" yang memagari manajemen Aksi Cepat Tanggap (ACT) agar tetap prudensial dan terpercaya: komunikasi, sosial dan niat.Tanggung jawab pihak Yayasan Aksi Cepat Tanggap (ACT) terhadap para relawan atau pegawai salah satunya dengan membangun rasa solidarisme antar relawan atau pegawai menyangkut kegiatan yang mendukung kelancaran misi kemanusiaan. Mereka sudah paham tentang rasa persatuan dan berjalan bersama untuk menjadi manusia pembawa solusi. Mereka memanfaatkan kedekatan hubungan kekerabatan untuk membangun solidaritas. Hubungan kekerabatan, rasa memiliki, kesetiaan atau loyalitas yang sangat tinggi, dan kiprah yang besar dalam pelayanan sosial ditanamkan oleh Yayasan Aksi Cepat Tanggap (ACT) kepada para relawan atau pegawainya. Hal ini dilakukan untuk membangun kedekatan secara emosional. Kesatuan tujuan dan pandangan inilah yang membawa kiprah dalam misi kemanusiaan mencapai pada titik maksimal.

Suatu lembaga atau komunitas ternyata mempunyai kekuatan dalam persatuan danpersaudaraan sehingga dapat mewujudkan kepedulian sosial di dalamnya. Hal inisesuai dengan makna sikap kepedulian sosial sebagai perasaan bertanggung jawabatas kesulitan yang dihadapi oleh orang lain di mana seseorang terdorong untukmelakukan sesuatu untuk mengatasinya. Kepedulian sosial di dalam kehidupanbermasyarakat lebih diartikan sebagai perilaku baik dari seseorang atau lembagaterhadap orang lain (komunitas) di sekitarnya yang butuh pertolongan karenaditimpa musibah atau kesulitan. Dalam Islam sikap peduli sangat dianjurkan. Halini menjadi aplikasi bentuk luhur budi pekerti seseorang kepada sesamanya.(Yosepin, 2018: 191)

Aksi Cepat Tanggap (ACT) memiliki akuntabilitas yang baik dinilai dari 
pelayanan dan pemenuhan kebutuhan yang sifatnya bukan hanya berbentuk barang dan bersifat intangible. Adapun pemenuhan kebutuhan masyarakat yang difasilitasi dapat dipertanggungjawabkan dengan kehadiran relawan, elemen masyarakat yang tergabung dalam kegiatan, dan pembaharuan laporan bantuan dari masyarakat. Dengan begitu, Aksi Cepat Tanggap (ACT) mendapatkan kepercayaan dari masyarakat dengan berwujud kontribusi dan dukungan.Aksi Cepat Tanggap (ACT) telah membuat sebuah perencanaan besar yang strategik dalam rangka upaya untuk mencapai tujuan organisasi. Hal tersebut dapat dilihat dari sepak terjang dan sejarah di awal berdiri dan kiprahnya hingga sampai saat ini yang berkembang pesat. Pencapaian saat ini adalah keberhasilan Aksi Cepat Tanggap (ACT) dalam sebuah perencanaan besar, sebuah konsep organisasi yang dicerminkan dalam visi dan misi dan kemudian direalisasikan dalam sebuah program yang realistis.

Dari sini dapat terlihat bahwa Aksi Cepat Tanggap (ACT) telah berhasil merumuskan pengelolaan yang strategik yang terbukti dari keberhasilannya saat ini menjadi sebuah organisasi sosial dan kemanusiaan yang dapat di pertanggungjawabkan dan terpercaya di Indonesia.(Soetomo, 2012: 118-122).

Akuntabilitas Aksi Cepat Tanggap (ACT) dapat dilihat pula dari visi dan misi yang kuat. Visi dan misi merupakan bagian dari rencana strategis yang berorientasi masa depan, hal ini relevan dengan prinsip pemberdayaan yaitu memiliki visi dan misi yang kuat. Aksi Cepat Tanggap (ACT) telah membuktikan bahwa visi dan misi yang disusun adalah sebuah cita-cita yang relistis dan kini telah terwujud menjadi sebuah organisasi sosial kemanusiaan yang bertanggungjawab. Dapat dilihat bahwa visi dan misi Aksi Cepat Tanggap (ACT) yang mempunyai nilai filosofi dan kuat.

Akuntabilitas sebagai modal sosial merupakan sebuah potensi yang muncul karena manusia adalah makhluk sosial sehinggatidak dapathidup sendirian. Manusiasenantiasa hidup berkelompoksertamenjalin komunikasi dan kerja samadengan sesamanya.Potensiyangdigunakanmanusiauntuk melakukansemua kegiatantersebut merupakanpotensi sosial. (Nashori, 2003: 89)

Dengan demikian, konsep tanggung jawab Aksi Cepat Tanggap (ACT) bisa digolongkan menjadi dua; pertama tanggung jawab terhadap individu atau dirinya sendiri sebagai manusia yang menjunjung nilai kemanusiaan khususnya antar sesama muslim. Dan kedua, tanggung jawab terhadap masyarakat sekitar, hal ini sejalan dengan konsep pemberdayaan masyarakat Islam yaitu merupakan aksi nyata pengembangan pola perilaku individual dan kolektif dalam dimensi amal saleh (karya terbaik), dengan titik tekan pada pemecahan masalah yang dihadapi oleh masyarakat. Sasaran individual yaitu setiap individu muslim, dengan orientasi sumber daya potensi sosial masyarakat. Sasaran komunal adalah kelompok atau komunitas muslim, dengan orientasi pengembangan sistem 


\section{Nuraeni}

masyarakat. Sasaran institusional adalah organisasi Islam dan pranata sosial kehidupan, dengan orientasi pengembangan kualitas dan islamitas kelembagaan.

\section{Transparansi Yayasan Aksi Cepat Tanggap (ACT)}

Aksi Cepat Tanggap (ACT) bersifat independen bebas bersikap dan mandiri, netral objektif tidak memihak dan bersikap proporsional, transparan menginformasikan kegiatan lembaga kepada para pemangku kepentingan, akuntabel mempertanggung jawabkan program kepada mitra, non diskriminatif tidak membedakan suku, ras, agama dan golongan. Dengan visi menjadi pelopor dalam menumbuhkan jiwa-jiwa peduli berbasis kerelawanan menuju kemandirian masyarakat, Aksi Cepat Tanggap (ACT) senantiasa mengusung nilai-nilai kepedulian, kerelawanan dan kemandirian masyarakat dalam menjalankan setiap programnya.

Pendanaan program-program Aksi Cepat Tanggap (ACT) berasal dari donasi publik dan dana Corporate Social Responbility (CSR) perusahaan, yang pemanfaatannya diaudit oleh akuntan publik sebagai bentuk transparansi kepada para pemangku kepentingan. Untuk menjangkau penerima manfaat yang tersebar hingga ke wilayah terpencil, dalam pelaksanaan program-programnya Aksi Cepat Tanggap (ACT) mengembangkan jaringan relawan lokal yang bernaung di bawah bendera Masyarakat Relawan Indonesia (MRI) atau Indonesian Volunteer Society. Adanya MRI membuat pelaksanaan program-program Aksi Cepat Tanggap (ACT) efisien dan efektif.Pendanaan tersebut diperlukan adanya partisipasiyang sesungguhnya berasal dari masyarakatitusendiri,ia adalah tujuan dalam suatu proses demokrasi. (Rukminto,2008: 106-107)

Dengan memanfaatkan modal sosial transparansi, Yayasan Aksi Cepat Tanggap (ACT) menjadi pilihan yang tepat dan cepat dalam menyalurkan berbagai bentuk bantuan kemanusiaan. Dengan adanya peran modal sosial ini, jaringan informal seperti bentuk kerelawanan dan formal berbasis global seperti lembaga filantropi lainnya pun terbangun akibat dari transparansi yang dibutuhkan masyarakat untuk mengetahui dan sebagai bentuk tanggung jawab. Dalam tatanan kehidupan, lingkungan lembaga pengembangan potensi sosial masyarakat merupakan bagian dari lingkungan kehidupan makronya. Dengan demikian di samping interaksi internal dalam pengembangan lembaga juga terjadi interaksi dengan lingkungan eksternalnya. Interaksi eksternal apalagi kecenderungan perubahan sosial yang terjadi pada level yang lebih makro pasti akanmemberikan pengaruh pada pengembangan potensi sosial lembaga kemanusiaan. Oleh sebab itu, interaksi yang didasari asas kepercayaan, tanggung jawab dan transparansi yang kemudian membentuk jaringan sosial kuat antarwarga dan antar kelompok-kelompok.(Soetomo, 2012: 118-122).

Sumber energi sosial dalam masyarakat berupa nilai kemandirian, solidaritas, kesadaran kolektif, tanggung jawab sosial yang mendorong 
terwujudnya tindakan bersama. Tidak dapat diingkari bahwa setiap orang sebagai individu mempunyai aspirasi, kepentingan yang dapat berbeda dengan orang lain sesama warga masyarakat. Untuk memenuhi kebutuhan dan kepentingannya tersebut setiap orang dapat melakukan tindakan yang bersifat individual. Walaupun demikian, dengan adanya energi sosial tersebut di samping tindakan individu, warga masyarakat juga dapat terlibat dalam tindakan bersama, bahkan dalam hal-hal tertentu menempatkannya di atas tindakan individu. Kehadiran energi sosial ini juga dapat menjadi pendorong semangat kemandirian masyarakat sebagai kesatuan, dengan menempatkan upaya untuk memelihara dan meningkatkan kesejahteraannya sebagai tanggung jawab masyarakat sendiri bukan menggantungkan pada pihak lain.Sumberdaya merupakan bagian yang sangat pentingdalam menunjang sebuah kinerja dalam pelaksanaan kegiatan yang merupakansuatu kesatuan baik potensi personil (SDM), ketersediaan dana, dan dukungansarana prasarana yang dapat dimanfaatkan dalam melaksanakan suatu kegiatan.(Ridwanullah, 2018: 94)

Dengan demikian, bentuk-bentuk pemberdayaan berbasis kemanusiaan yang telah dilaksanakan oleh Aksi Cepat Tanggap (ACT) mampu memberikan titik terang kepada masyarakat kota Bandung dalam menyalurkan potensi sosialnya berwujud kerelawanan, donatur dan kepedulian terhadap kesejahteraan serta keberdayaan masyarakat. Khususnya masyarakat sesama muslim yang membutuhkan pertolongan baik dalam segi materi ataupun non materi. Dengan memanfaatkan modal sosial transparansi, Yayasan Aksi Cepat Tanggap (ACT) menjadi pilihan yang tepat dan cepat dalam menyalurkan berbagai bentuk bantuan kemanusiaan. Dengan adanya peran modal sosial ini, jaringan informal seperti bentuk kerelawanan dan formal berbasis global seperti lembaga filantropi lainnya pun terbangun akibat dari transparansi yang dibutuhkan masyarakat untuk mengetahui dan sebagai bentuk tanggung jawab.

Jika dilihat dari tiga aspek yaitu akuntabilitas, transparansi, dan trust sebagai penilaian maka dapat disimpulkan yaitu Aksi Cepat Tanggap (ACT) memiliki akuntabilitas yang baik dinilai dari pelayanan dan pemenuhan kebutuhan yang sifatnya bukan hanya berbentuk barang dan bersifat intangible. Adapun pemenuhan kebutuhan masyarakat yang difasilitasi dapat dipertanggungjawabkan dengan kehadiran relawan, elemen masyarakat yang tergabung dalam kegiatan, dan pembaharuan laporan bantuan dari masyarakat. Dengan begitu, Aksi Cepat Tanggap (ACT) mendapatkan kepercayaan dari masyarakat dengan berwujud kontribusi dan dukungan. Pelaksaan program pemberdayaan yang dilakukan berguna untuk meningkatkan tanggung jawab, kepedulian sosial dan memberikan kesempatan pada masyarakat untuk dapat mengembangkan segala kemampuan dalam rangka membangun kesejahteraan dan kemaslahatan umat. Perubahan pada titik kepercayaan, tanggung jawab dan transparansi dinilai dari banyaknya 


\section{Nuraeni}

amanat yang masyarakat titipkan kepada Aksi Cepat Tanggap (ACT). Peningkatan hidup masyarakat dapat menjadikan pilihan yang bermanfaat untuk mengatasi segala kesulitan hidup, pemecahan masalah dalam krisis kemanusiaan yang utama sesuai dengan syariat $\mathrm{Al}$ quran dan sunnah.

Hasil yang ditemukan oleh peneliti yaitu Aksi Cepat Tanggap (ACT) Bandung tidak berdiri sendiri, namun terkordinasi dengan Aksi Cepat Tanggap (ACT) pusat. Keuntungannya adalah segala pengendalian masih dapat dipantau dan diawasi pusat, namun tidak membatasi kewenangan cabang untuk mengambil keputusan secara tepat ketika harus melakukan tindakan yang bersifat penting dan darurat. Selain itu, pelibatan manajemen puncak dalam Aksi Cepat Tanggap (ACT) ketika dalam urusan keuangan akanselalu terkoordinasi oleh pusat (Soetomo, 2012: 118-122).

\section{PENUTUP}

Berdasarkan pada pembahasan yang telah diuraikan sebelumnya yaitu mengenai pemberdayaan potensi sosial masyarakat yang dilakukan oleh Aksi Cepat Tanggap (ACT) Bandung, maka penulis mengambil kesimpulan terhadap penelitian ini sebagai berikut:Pertama, perkembangan Aksi Cepat Tanggap (ACT) sebagai sebuah lembaga berbasis kemanusiaan hingga sebesar sekarang meniscayakan bahwa masyarakat telah mengerti bagaimana visi dan misi lembaga dirumuskan, serta mengikuti dari waktu ke waktu hingga bagaimana kepercayaan tinggi diberikan masyarakat kepada Aksi Cepat Tanggap (ACT). Banyak sekali lembaga-lembaga tumbuh kembang menjadi besar dari donasi masyarakatyang begitu masif.Dengan menggulirkan aksi-aksi kemanusiaan, Aksi Cepat Tanggap (ACT) mampu menciptakan kepercayaan masyarakat yang ditandai dengan besarnya amanat dan kontribusi masyarakat. Kegesitan Aksi Cepat Tanggap (ACT) menerima amanat dan menyalurkan secara cepat, banyak menuai apresiasi dari lapisan masyarakat. Seperti contohnya adalah Walikota Bandung mempercayakan donasi masyarakatnya untuk disalurkan oleh Aksi Cepat Tanggap (ACT) dalam misi kemanusiaan.

Lembaga kemanusiaan basisnya adalah trust. Semakin tinggi kepercayaan yang dimiliki sebuah lembaga sosial kemanusiaan, semakin besar donasi (dalam bentuk dana dan barang) mengalir kepadanya. Kepercayaan yang makin tinggi, melahirkan amanat besar. Amanat besar menuntut kapasitas besar (hebat). Kapasitas yang makin besar melahirkan kepercayaan yang makin besar. Kedua, Aksi Cepat Tanggap senantiasa memperbaharui laporan donasi dan di audit oleh Kantor Akuntan Publik Independen (Independent Auditor's Report), pada prinsipnya Aksi Cepat Tanggap (ACT) sangat menjunjung asas prudensialitas, sehingga publik dapat berdonasi dengan pertanggungjawaban yang baik.

Adapun manajemen Aksi Cepat Tanggap (ACT) agar tetap prudensial dan terpercaya yaitu; komunikasi, sosial dan niat. Pertama, audit komunikasi yaitu 
parameter capaian komunikasi yang diukur tanpa campur tangan lembaga khusus, tidak lebih rendah derajat objektivitasnya. Kedua, audit sosial. Ini terkait kemanfaatan program Aksi Cepat Tanggap (ACT). Sebelum diaudit publik dalam arti publik memandang implementasinya baik, progresif atau tidak layak, dan mengada-ada bahwa Aksi Cepat Tanggap (ACT) sudah melakukan self-audit. Ketiga, "audit niat". Ini disadari orang per orang. Setiap individu diajak berefleksi, seberapa hebat niat berkarya di Aksi Cepat Tanggap (ACT). Tanpa niat kuat dan pikiran luas berfilantropi, tanpa niat kuat untuk beribadah, bekerja di Aksi Cepat Tanggap (ACT) akan menjadi siksaan.

Maka, "luruskan niat" menjadi saran pertama bagi individu baru Aksi Cepat Tanggap (ACT). Yang ini, tentu setiap orang tak bisa menakarnya, sudah kewenangan Allah. Ketiga, Aksi Cepat Tanggap (ACT) bersifat independen bebas bersikap dan mandiri, netral objektif tidak memihak dan bersikap proporsional, transparan menginformasikan kegiatan lembaga kepada para pemangku kepentingan, akuntabel mempertanggung jawabkan program kepada mitra, non diskriminatif tidak membedakan suku, ras, agama dan golongan. Pendanaan program-program Aksi Cepat Tanggap (ACT) berasal dari donasi publik dan dana Corporate Social Responbility (CSR) perusahaan, yang pemanfaatannya diaudit oleh akuntan publik sebagai bentuk transparansi kepada para pemangku kepentingan.

Dengan memanfaatkan modal sosial transparansi, Aksi Cepat Tanggap (ACT) menjadi pilihan yang tepat dan cepat dalam menyalurkan berbagai bentuk bantuan kemanusiaan. Dengan adanya peran modal sosial ini, jaringan informal seperti bentuk kerelawanan dan formal berbasis global seperti lembaga filantropi lainnya pun terbangun akibat dari transparansi yang dibutuhkan masyarakat untuk mengetahui dan sebagai bentuk tanggung jawab.

\section{DAFTAR PUSTAKA}

Aliyudin, M. (2009). Pengembangan Masyarakat Islam dalam Sistem Dakwah Islamiah dalam Ilmu Dakwah: Academi Journal for Homiletic Studies. 4(14), 789

Kartasasmita. (1997). Pemberdayaan Masyarakat: Konsep Pembangunan yang Berakar Pada Masyarakat. Jakarta: BAPPENAS

Koentjaraningrat. (2009). Pengantar Ilmu Antropologi. Jakarta: Rineka Cipta

Mustangin dkk. (2017).Pemberdayaan Masyarakat Berbasis Potensi Lokal melalui Program Desa Wisata di Desa Bumiaji. Sosioglobal : Jurnal Pemikiran dan Penelitian Sosiologi, 2(1), 59-72.

Muhaimin,D.A.(2013).Generasi Muda Bicara Pancasila. Yogyakarta: Ombak 
I. Nuraeni

Mustangin dkk. (2017).Pemberdayaan Masyarakat Berbasis Potensi Lokal melalui Program Desa Wisata di Desa Bumiaji. Sosioglobal : Jurnal Pemikiran dan Penelitian Sosiologi, 2(1), 59-72.

Nashori.(2003). Potensi-Potensi Manusia. Yogyakarta: Pustaka Pelajar

Ridwanullah, A.I. (2018). Optimalisasi Pemberdayaan Masyarakat Berbasis Masjid. Ilmu Dakwah: Academi Journal for Homiletic Studies , 1(12), 82-98.

Rukminto. (2008). Intervensi Komunitas Pengembangan Masyarakat Sebagai Upaya Pemberdayaan Masyarakat. Jakarta: PT Raja Grafindo Persada

Safei, AA. (2016). The Development of Islamic Society Based on Celestial Business". Walisongo Jurnal Penelitian Sosial Keagamaan. 24(1), 1-16.

Surakhmad. (1982). Pengantar Penelitian Ilmiah. Bandung: Tarsito

Suharto, E. (2005). Membangun Masyarakat Memberdayakan Rakyat (Kajian Strategis Pembangunan Kesejabteraan Sosial dan Pekerjaan Sosial). Bandung: PT Refika Aditama

Sukmana, Oman. (2010). Konsep Pemberdayaan Masyarakat melalui Pengembangan Komunitas Berbasis Potensi Lokal (Studi Di Desa Wisata Bunga Sidomulyo, Kota batu Jawa Timur). HUMANITY, 6(1), 59 -64 .

Sumardjan, S. (1964). Setangkai Bunga Sosiologi. Jakarta: Lembaga Penerbit Fakultas Ekonomi UI

Teguh, A. (2004). Kemitraan dan Model-Model Pemberdayaan. Yogyakarta: Graha Ilmu

Wiyono, S. (2006). Otonomi Daerah dalam Negara Hukum Indonesia. Jakarta: Faja Media

Yosepin. (2018). Revitalisasi Masjid melalui Kepedulian Sosial Lembaga Takmir Masjid Nahdlatul 'Ulama (LTM NU) terhadap Komunitas Pengemudi. Ilmu Dakwah: Academic Journal for Homiletic Studies, 1(12), 121-140. 